Sains Malaysiana 49(12)(2020): 3055-3063

http://dx.doi.org/10.17576/jsm-2020-4912-17

\title{
Seed-Mediated Synthesis and Photoelectric Properties of Selenium Doped Zinc Oxide Nanorods
}

(Sintesis Bermediasi Benih dan Sifat Fotoelektrik Selenium Terdop Nanorod Zink Oksida)

\author{
Ari Sulistyo Rini*, Yolanda Rati, Miranti Agustin, Yanuar Hamzah \& Akrajas Ali Umar
}

\begin{abstract}
Pristine $\mathrm{ZnO}$ and selenium doped $\mathrm{ZnO}$ (Se-ZnO) nanorods were successfully synthesized using seed-mediated hydrothermal method. The growth solution of both pure and Se-doped ZnO nanorods employed zinc nitrate hexahydrate (ZNH) and hexamethylenetetramine (HMT) as a precursor and surfactant, respectively. As a dopant source, selenium salt solution was obtained by reacting selenium powder with sodium borohydride at low temperature. The as-prepared pure $\mathrm{ZnO}$ and Se-doped $\mathrm{ZnO}$ nanorods were characterized using field effect scanning electron microscopy (FESEM), $X$-ray diffraction (XRD), UV-Visible spectroscopy (UV-Vis), and Photoluminescence (PL) spectroscopy. FESEM images show that the geometric shape of Se-ZnO nanoparticles is nanorods with a hexagonal cross-section. The XRD pattern shows the diffraction peak of the sample at the angles of $2 \theta: 34.44^{\circ}, 36.25^{\circ}$ and $47.54^{\circ}$ which represents the $h k l$ plane of (002), (101) and (102), respectively. The crystalline size calculated from XRD data is found to be in the range of 35-42 $\mathrm{nm}$. The UV-Vis spectrum shows that Se-ZnO nanorods strong absorption peaks appeared in the range of $300-380 \mathrm{~nm}$ for all samples. Se doping has slightly altered the band gap energy of pure ZnO nanorods around $0.01 \mathrm{eV}$. The peak of the photoluminescence spectra of the sample at $470 \mathrm{~nm}$ indicates the blue emission band.
\end{abstract}

Keywords: FESEM; PL spectra; selenium doping; UV-Vis; XRD; zinc oxide

ABSTRAK

$\mathrm{ZnO}$ asli dan selenium terdop nanorod $\mathrm{ZnO}$ (Se-ZnO) berjaya disintesis menggunakan kaedah hidroterma biji benih. Larutan pertumbuhan bagi kedua-dua $\mathrm{ZnO}$ asli dan Se-ZnO adalah menggunakan zink nitrat heksahidrat (ZNH) dan hexametilenetetramina (HMT) masing-masing sebagai pelopor dan surfaktan. Sebagai sumber pengedopan, larutan garam selenium diperoleh daripada tindak balas serbuk selenium dengan natrium borohidrida pada suhu rendah. $\mathrm{ZnO}$ asli dan Se-ZnO dicirikan menggunakan mikroskopi elektron imbasan pancaran medan (FESEM), pembelauan sinar-X (XRD), spektroskopi UV (UV-Vis) dan spektroskopi fotoluminesen (PL). Imej FESEM menunjukkan bentuk geometri nanozarah Se-ZnO adalah nanorod dengan keratan rentas heksagon. Corak XRD pula menunjukkan puncak belauan sampel pada sudut 20: $34.44^{\circ}, 36.25^{\circ}$ dan $47.54^{\circ}$ yang mewakili satah hkl masing-masing pada (002), (101) dan (102). Saiz kristal yang dihitung daripada data XRD berada dalam julat 35-42 $\mathrm{nm}$. Spektrum UV-Vis menunjukkan bahawa puncak penyerapan nanorod Se-ZnO muncul pada julat 300-380 nm untuk semua sampel. Pengedopan Se mengubah sedikit tenaga jurang jalur nanorod ZnO tulen sekitar $0.01 \mathrm{eV}$. Puncak spektra fotoluminesen pula muncul pada $470 \mathrm{~nm}$ menunjukkan jalur pancaran biru.

Kata kunci: FESEM; pengedopan selenium; spektra PL; UV-Vis; XRD; zink oksida

\section{INTRODUCTION}

$\mathrm{ZnO}$ (Zinc Oxide) is a II-VI group semiconductor that possesses wide band gap (3.37 eV) and large exciton binding energy $(60 \mathrm{MeV})$ with high photosensitivity, piezoelectric, and pyroelectric properties (Janotti \& Van De Walle 2009). ZnO, with the exciton binding energy of $60 \mathrm{MeV}$, might efficiently produce electron emission in ultraviolet range $(<400 \mathrm{~nm})$ at room temperature. These properties have made $\mathrm{ZnO}$ applicable in several devices such as solar cells (Luo et al. 2018), LEDs (Light-Emitting Devices), gas sensors (Zhu \& Zeng 2017), biosensors (Karim et al. 2019), piezoelectric transducers (Zakaria et al. 2017), and pyroelectric devices (Tan et al. 2009). ZnO is a versatile material that can substitute $\mathrm{TiO}_{2}$ in several application because $\mathrm{ZnO}$ has good transparency and higher electron mobility (Rong et al. 2019). In addition, $\mathrm{ZnO}$ has low defects (Thangavel \& Chang 2012), and can be easily 
fabricated in various nanostructures at low temperature (Singh 2013). In order to enhance the properties of $\mathrm{ZnO}, \mathrm{ZnO}$ is normally doped with different impurities to develop fascinating characteristics. This is accomplished by creating the desired properties and functions, including altering the band structure, establishing defect sites and promoting the mobility of charge carriers (Taha et al. 2019). In many application such as solar cells, catalyst and sensors, it is essential to adjust the electrical, optical and magnetic properties of $\mathrm{ZnO}$ (Chen et al. 2017; Nenavathu et al. 2018).

$\mathrm{ZnO}$ is commonly doped by various impurity such as metal In (Abrar et al. 2012), B (Rahman et al. 2016), Mg (Corral-Aguado et al. 2016), Mn (Achouri et al. 2016), $\mathrm{Ni}$ (Yilmaz et al. 2012), Al (Thu \& Maenosono 2010), Ga (Alexandrov et al. 2020), Li (Alexandrov et al. 2020) or nonmetal N (Bangbai et al. 2013), C (Alshammari et al. 2015), S (Wang et al. 2013), and Se (Taha et al. 2019). Doping of $\mathrm{ZnO}$ with nonmetals might affect the band gap and the photoelectronic properties of undoped $\mathrm{ZnO}$ nanoparticles (Chen et al. 2008). Selenium (Se) was selected because of its excellent chemical properties (Chen et al. 2017). In addition, the high reduction potential of Se is a desirable condition for the extraction of photoexcited electrons from the conduction band ( $\mathrm{CB})$ and can therefore promote the production of reactive oxygen species (Nenavathu et al. 2018).

$\mathrm{ZnO}$ doping with Se has enhanced photoelectrochemical and photocatalytic properties of $\mathrm{ZnO}$ (Chen et al. 2017). Se-doped $\mathrm{ZnO}$ (Se-ZnO) NPs has previously been synthesized using thermomechanical methods (Nenavathu et al. 2018), photoelectrochemistry (Chen et al. 2017), chemical vapor transportation methods (Kumar et al. 2002), and sol-gel methods (Mustafa et al. 2018). However, these methods need complicated devices and are conducted at high temperature. In this work, the undoped and Se-doped $\mathrm{ZnO}$ nanorods were synthesized using a seed-mediated hydrothermal method at low temperatures. Doping of $\mathrm{ZnO}$ with low addition of Se was rarely studied. In this report, Se-doped $\mathrm{ZnO}$ nanorods was prepared by adding $0.025,0.05,0.1$, and $0.2 \mathrm{~mL}$ of Se salt solution into the growth solution. Characterizations involved in this study were field effect scanning electron microscope (FESEM), X-ray diffraction (XRD), ultraviolet-visible absorption spectroscopy (UVVis), and photoluminescence (PL).

\section{MATERIAL AND METHODS}

\section{MATERIAL}

Zinc acetate dihydrate $\mathrm{Zn}\left(\mathrm{CH}_{3} \mathrm{COO}\right)_{2} .2 \mathrm{H}_{2} \mathrm{O}(\geq 99.0 \%$ ACS Reagent) hexamethylenetetramine (HMT) $\left(\mathrm{CH}_{2}\right)_{6} \mathrm{~N}_{4}$ (>99.0\% ACS Reagent) and Fluorine-doped Tin Oxide (FTO) glasses were purchased from Sigma Aldrich. Zinc nitrate hexahydrate, $\mathrm{Zn}\left(\mathrm{NO}_{3}\right)_{2} \cdot 6 \mathrm{H}_{2} \mathrm{O}$ (Analytical Reagent) and Se powder were obtained from R\&M Chemicals. Absolute ethanol $\mathrm{C}_{2} \mathrm{H}_{5} \mathrm{OH}(99 \%)$ and acetone ( 97\%) were provided by $\mathrm{HmbG}{ }^{\circledR}$ Chemicals. Deionized water was obtained from Millipore water system.

\section{SYNTHESIS OF ZNO AND SE-ZNO NANORODS}

The pristine $\mathrm{ZnO}$ and $\mathrm{Se}-\mathrm{ZnO}$ nanorods were grown on an FTO substrate using seed-mediated hydrothermal methods. Previously, the FTO substrate was subsequently cleaned by distilled water, acetone, and ethanol for $15 \mathrm{~min}$ using an ultrasonic bath. $\mathrm{ZnO}$ seeds solution was made by dissolving $22 \mathrm{mg}$ of zinc acetate dihydrate into $10 \mathrm{~mL}$ of absolute ethanol. The solution was dropped on the FTO substrate and then spin-coated with a rotation speed of 3000 rpm for the $30 \mathrm{~s}$. The sample was heated using a hotplate at $100{ }^{\circ} \mathrm{C}$ for $15 \mathrm{~min}$. The coating process was repeated 3 times to get uniform $\mathrm{ZnO}$ seed.

$\mathrm{ZnO}$ growth solution was prepared by dissolving equimolar $10 \mathrm{mM}$ zinc nitrate hexahydrate and $10 \mathrm{mM}$ hexamethylenetetramine. As a dopant source, selenium salt solution was previously prepared by reacting selenium powder with $100 \mathrm{mM}$ sodium borohydride at low temperature. Doping concentration was controlled by varying the selenium salt solution volumes in the growth solution $(0.025,0.05,0.1$, and $0.2 \mathrm{~mL})$. Those samples were named according to their selenium solution volume $(\mathrm{ZnO}+\mathrm{Se} 0.025 \mathrm{~mL}, \mathrm{ZnO}+\mathrm{Se} 0.05 \mathrm{~mL}, \mathrm{ZnO}+$ $\mathrm{Se} 0.1 \mathrm{~mL}$, and $\mathrm{ZnO}+\mathrm{Se} 0.2 \mathrm{~mL}$ ). $\mathrm{ZnO}$ seeds films were then vertically immersed in the growth solution and heated at $90{ }^{\circ} \mathrm{C}$ for $5 \mathrm{~h}$. After the growth process is completed, the sample is taken out from the solution and then cleaned with a copious amount of deionized water.

\section{MATERIAL CHARACTERIZATION}

The morphology of the samples was obtained using field emission scanning electron microscope (FESEM, ZEISS MERLIN type, Compact Co. Ltd.). The crystal structure was determined by X-ray diffraction (XRD, using a BRUKER EIXS type diffractometer). The UVVis spectrophotometer HITACHI U-3900H was used to characterize the UV-Vis diffuse reflectance spectra of the samples. The fluorescence measurements of the obtained films were performed in and FLS920 photoluminescence spectrometers (Edinburgh instruments).

\section{RESULTS AND DISCUSSION}

\section{SURFACE MORPHOLOGY}

The FESEM of $\mathrm{ZnO}$-pure and Se-ZnO nanorod synthesized using the seed. The FESEM image of undoped and Se-doped $\mathrm{ZnO}$ samples indicated the morphology of nanorod with hexagonal cross-section. Figure 1(B), 1(D), 1(F), 1(H), 1(J) shows the particle size distribution of $\mathrm{ZnO}$ nanorods grown on the substrate. It is clearly seen that $\mathrm{ZnO}$ 
nanorod grows more evenly and more densely after the addition of Se elements into the $\mathrm{ZnO}$ compounds. Based on the histogram graph in Figure 1, the mean rods diameter of the samples tends to increase. The rods diameter of pristine $\mathrm{ZnO}$ sample are $46.89 \pm 15.9 \mathrm{~nm}$, while the rod diameter of Se-doped $\mathrm{ZnO}$ sample are increased up to 64.68 $\pm 18.0 \mathrm{~nm}$. An increase in nanorod size might be due to the ionic radius of $\mathrm{Se}^{2-}(190 \mathrm{pm})$ larger than that of $\mathrm{O}^{2-}(140$ $\mathrm{pm}$ ) which influence the molecule size of $\mathrm{Se}-\mathrm{ZnO}$ mediated hydrothermal method are shown in Figure 1. The FESEM image was captured with 30,000 times of magnification. Particle size distribution (nanorod diameter) of the $\mathrm{ZnO}$ pure and Se-doped $\mathrm{ZnO}$ samples are presented in Table 1.
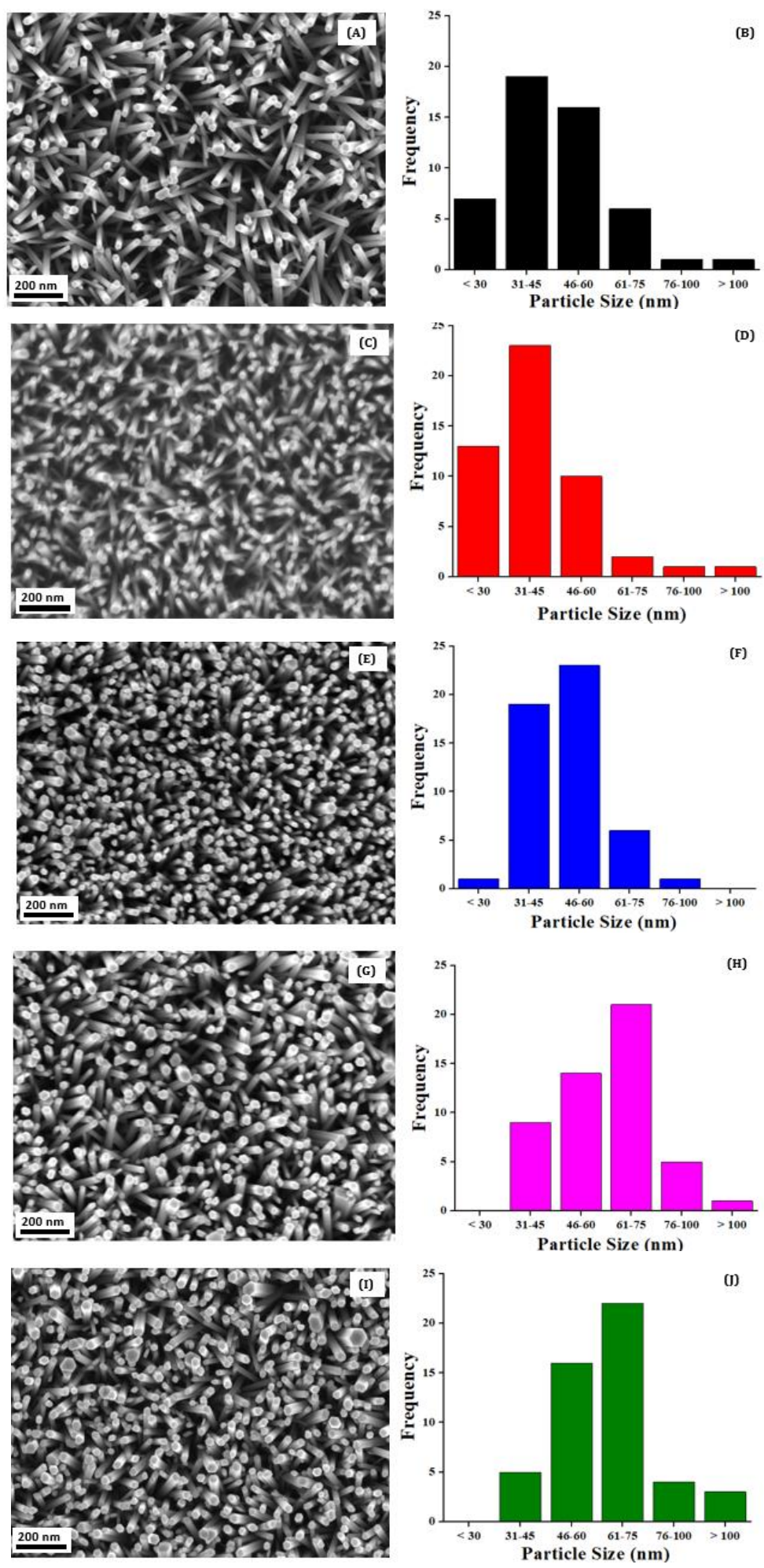

FIGURE 1. FESEM Images and particle size distribution of $\mathrm{ZnO}$ Pure (A,B), ZnO + Se $0.025 \mathrm{~mL}$ (C,D), ZnO + Se $0.05 \mathrm{~mL}$ (E,F), $\mathrm{ZnO}+\mathrm{Se} 0.1 \mathrm{~mL}(\mathrm{G}, \mathrm{H})$, and $\mathrm{ZnO}+\mathrm{Se} 0.2 \mathrm{~mL}(\mathrm{I}, \mathrm{J})$ 
TABLE 1. Particle size distribution data of the sample $\mathrm{ZnO}$ pure and $\mathrm{Se}-\mathrm{ZnO}$

\begin{tabular}{cc}
\hline Sample & Nanorod diameter $(\mathrm{nm})$ \\
\hline ZnO Pure & $46.89 \pm 15.9$ \\
$\mathrm{ZnO}+\mathrm{Se} 0.025 \mathrm{~mL}$ & $38.78 \pm 10.7$ \\
$\mathrm{ZnO}+\mathrm{Se} 0.050 \mathrm{~mL}$ & $48.68 \pm 11.1$ \\
$\mathrm{ZnO}+\mathrm{Se} 0.100 \mathrm{~mL}$ & $60.72 \pm 16.7$ \\
$\mathrm{ZnO}+\mathrm{Se} 0.200 \mathrm{~mL}$ & $64.68 \pm 18.0$ \\
\hline
\end{tabular}

Based on Table 1, the addition of Se to $\mathrm{ZnO}$ affects the size of the nanorod diameter of the grown sample. $\mathrm{ZnO}+\mathrm{Se} 0.025 \mathrm{~mL}$ and $\mathrm{ZnO}+\mathrm{Se} 0.05 \mathrm{~mL}$ samples nanorods diameter are $38.78 \pm 10.7 \mathrm{~nm}$ and $48.68 \pm 11.1$ $\mathrm{nm}$, respectively. Table 1 and the histogram in Figure 1(d), 1(f) indicates $\mathrm{ZnO}+\mathrm{Se} 0.025 \mathrm{~mL}$ and $\mathrm{ZnO}+\mathrm{Se} 0.05 \mathrm{~mL}$ samples have the lowest standard deviation with more than $40 \%$ nanorod diameter in the range of $31-45 \mathrm{~nm}$ and $46-60 \mathrm{~nm}$, respectively. It is clearly seen that Se doping decrease nanorods size as well as improve size distibution. Fortunately, doping that creates uniform nanorods mostly can enhance the optical and electrical properties of the $\mathrm{ZnO}$ nanostructure (Kim et al. 2014).

\section{CRYSTAL STRUCTURE}

The XRD pattern of pristine $\mathrm{ZnO}$ and Se-doped $\mathrm{ZnO}$ ( $\mathrm{Se}-\mathrm{ZnO}$ ) nanorods are shown in Figure 2. There are five diffraction peaks detected at $2 \theta$ of $34.44^{\circ}, 36.25^{\circ}, 37.78^{\circ}$, $47.54^{\circ}$, and $51.63^{\circ}$. The $2 \theta$ of $34.44^{\circ}, 36.25^{\circ}$, and $47.54^{\circ}$ correspond to reflection plane of $\mathrm{ZnO}$ hkl plane of (002), (101), and (102). The other two peaks with asterisk $(*)$ refer to FTO plane of (220) and (211). The diffraction peaks of both undoped and Se doped $\mathrm{ZnO}$ samples indicates the hexagonal wurtzite $\mathrm{ZnO}$ (JCPDS No. 01-070-8070) (Chen et al. 2017). The highest diffraction peak at (002) suggests the growth direction of the $\mathrm{Se}-\mathrm{ZnO}$ nanorod along the c-axis which is perpendicular to the FTO surface. The similar results are also reported previously (Taha et al. 2019) for $\mathrm{ZnO}$ doped with $2 \%$ mol of Se.

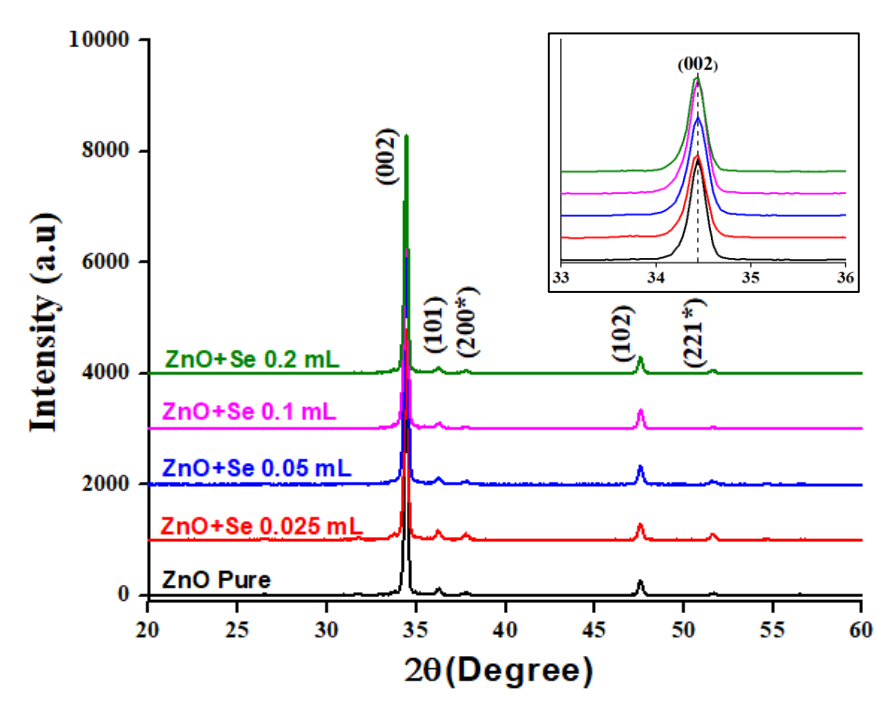

FIGURE 2. XRD patterns of $\mathrm{ZnO}$ pure and Se doped O. Inset is magnification of (002) peaks 
The inset of Figure 2 displays the magnification of the (002) peaks of the undoped and Se doped $\mathrm{ZnO}$ nanorods. The peak posisiton of doped $\mathrm{ZnO}$ slightly shifted towards lower angles relative to that of undoped $\mathrm{ZnO}$. It is indicating that the Se had succesfully penetrated into the $\mathrm{ZnO}$ lattice (Chen et al. 2017) and increased the lattice parameters (Wang et al. 2015). The crystal size (D) of the sample can be calculated by the Debye-Scherrer equation (Patterson 1939).

$$
D=\frac{k \lambda}{\beta \cos \theta}
$$

where $k, \lambda, \beta$, and $\theta$ represent a constant equal to 0.90 , the wavelength of the incident X-ray (1.5406 $\AA$ ), full width at half maximum (FWHM) and peak position (in degree), respectively. Peak widening of FWHM is associated with reduced crystal size. Crystallite size were estimated from the strogest peak (002) data, and the lattice parameter were calculated from (101) and (002) peak, as shown in Table 2 .

TABLE 2. Crystallite size and lattice constant values for the undoped and Se doped $\mathrm{ZnO}$ samples

\begin{tabular}{ccccccc}
\hline Sample & $2 \theta\left(^{\circ}\right)$ & $\beta_{\text {FwнM }}\left({ }^{\circ}\right)$ & $\mathrm{D}(\mathrm{nm})$ & $\mathrm{a}=\mathrm{b}(\AA)$ & $\mathrm{c}(\AA)$ & $\mathrm{c} / \mathrm{a}$ \\
\hline ZnO Pure & 36.436 & 0.226 & 38.2 & 3.257 & 5.206 & 1.598 \\
$\mathrm{ZnO}+\mathrm{Se} 0.025 \mathrm{~mL}$ & 36.434 & 0.245 & 35.3 & 3.257 & 5.214 & 1.601 \\
$\mathrm{ZnO}+\mathrm{Se} 0.05 \mathrm{~mL}$ & 34.434 & 0.237 & 36.5 & 3.256 & 5.214 & 1.601 \\
$\mathrm{ZnO}+\mathrm{Se} 0.1 \mathrm{~mL}$ & 34.435 & 0.208 & 41.6 & 3.257 & 5.206 & 1.598 \\
$\mathrm{ZnO}+\mathrm{Se} 0.2 \mathrm{~mL}$ & 34.435 & 0.218 & 39.6 & 3.256 & 5.206 & 1.600 \\
\hline
\end{tabular}

At lower Se doping concentration $(\mathrm{ZnO}+\mathrm{Se} 0.025$ $\mathrm{mL}$ and $\mathrm{ZnO}+\mathrm{Se} 0.05 \mathrm{~mL}$ ), the diffraction peak intensity is reduced along with FWHM broadening. Broadening of FWHM is associated with the reduction of crystallite size of $\mathrm{ZnO}$ due to the incorporation of Se into $\mathrm{ZnO}$ (Nenavathu et al. 2018). Decreasing of the Se-doped $\mathrm{ZnO}$ crystalline size might be due to te $\mathrm{Se}^{+4}(0.050 \mathrm{~nm})$ displacement of $\mathrm{Zn}^{+2}$ (0.074) in the $\mathrm{ZnO}$ matrix (Taha et al. 2019). This reduction in crystallite size is similar to the previous report on the synthesis of Se-doped $\mathrm{ZnO}$ NPs (Taha et al. 2019). However, at the higher Se doping concentration $(\mathrm{ZnO}+\mathrm{Se} 0.1 \mathrm{~mL}$ and $\mathrm{ZnO}+\mathrm{Se} 0.2 \mathrm{~mL})$, the intensity of diffraction peaks are increased. This results is also consistent with Wang et al. (2019), which states that the peak intensity will increase with increasing doping volume up to $0.1 \%$. $\mathrm{ZnO}+\mathrm{Se} 0.1 \mathrm{~mL}$ sample has the largest crystal size or the highest crystallinity. The lattice parameter slightly changes compared to the pure $\mathrm{ZnO}$ sample. Changes in lattice parameters were also observed in Se-doped $\mathrm{ZnO}$ films made using the thermomechanical method. The lattice parameter enlargment indicates that $\mathrm{Se}$ is integrated at both the interstitial and the $\mathrm{O}$ sites (Bae et al. 2004). The lattice parameters of $\mathrm{ZnO}+\mathrm{Se} 0.05 \mathrm{~mL}$ and $\mathrm{ZnO}+\mathrm{Se} 0.2 \mathrm{~mL}$ samples are slightly reduced \pm 0.001 $\AA$. The lattice c parameters of the $\mathrm{ZnO}+\mathrm{Se} 0.025 \mathrm{~mL}$ and $\mathrm{ZnO}+\mathrm{Se} 0.05 \mathrm{~mL}$ samples increased by $0.008 \AA$. Aspect ratio (c/a) of the pure $\mathrm{ZnO}$ and $\mathrm{Se}-\mathrm{ZnO}$ samples are around 1.6. The aspect ratio values obtained are by the values obtained in the research conducted by Mustafa et al. (2018).

\section{OPTICAL PROPERTIES}

To analyze undoped and Se doped $\mathrm{ZnO}$ samples, with reflectance and absorbance measurements was performed
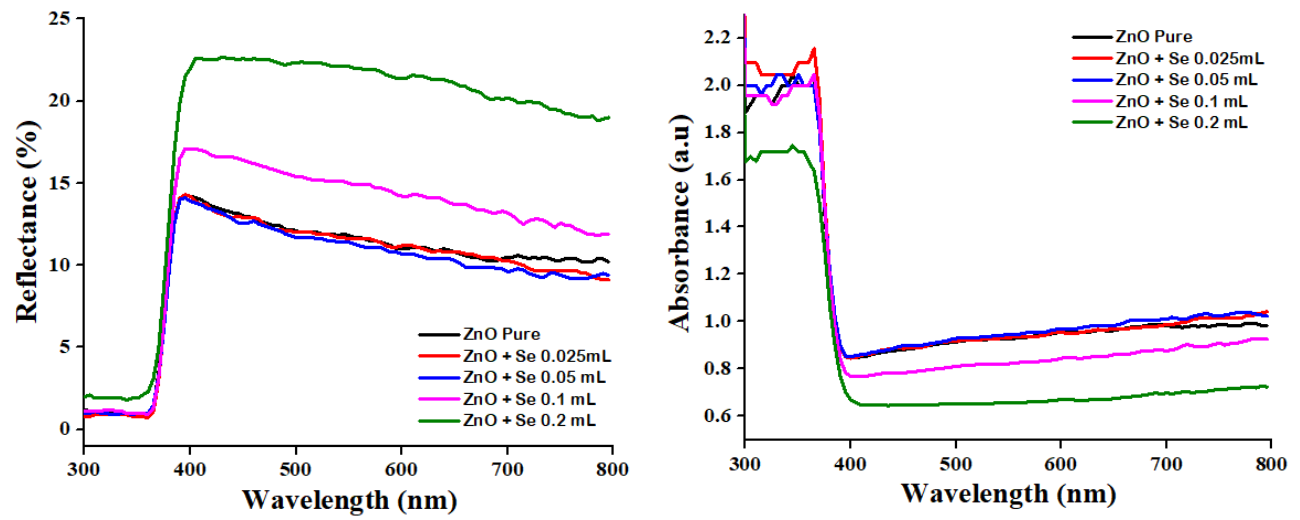

FIGURE 3. (a) Reflectance and (b) Absorbance spectra of $\mathrm{ZnO}$ and Se-doped $\mathrm{ZnO}$ samples with different dopant volume 
using a UV-Vis spectrophotometer in the wavelength range of $300-800 \mathrm{~nm}$. The UV-Vis reflectance and absorbance spectra of $\mathrm{ZnO}$ and Se-doped $\mathrm{ZnO}$ with different dopant volume are displayed in Figure 3(a) and 3(b).

The UV-Vis reflectance and absorbance spectra of $\mathrm{ZnO}$ and Se-doped $\mathrm{ZnO}$ with different dopant volume are displayed in Figure 3(a) and 3(b). For all samples, weak reflectance occurs in the range of 300-380 nm of wavelength, while the strong reflectance occurs in the range of 380-800 $\mathrm{nm}$ of wavelength. The highest strong reflectance spectrum belongs to the $\mathrm{ZnO}+\mathrm{Se} 0.2 \mathrm{~mL}$ sample and the lowest strong reflectance belongs to $\mathrm{ZnO}+\mathrm{Se} 0.05 \mathrm{~mL}$ sample. The strong reflectance peak shift toward the wavelength of visible light (red shift).

The absorption spectrum of the sample is shown in Figure 3(b). In the figure, it can be seen that the absorption intensity is inversly related to the reflectance intensity. The peak absorption of the $\mathrm{ZnO}$ nanorods occurs in the range of ultraviolet (UV) wavelength (Wang et al. 2019). The weak absorption occurs in the visible range which indicates the characteristics of the $\mathrm{ZnO}$ semiconductor (Sutanto et al. 2016). The increase in absorption intensity in the 300-380 wavelength range suggests more electrons from the sample being excited from a lower energy level to a higher energy level.

The band gap energy of each sample can also be determined from the reflectance and absorbance spectra. The band gap energy of the sample can be estimated using the Tauc plot equation,

$$
\alpha h v^{n}=A(h v-E g)
$$

where $\alpha, \mathrm{h}, \mathrm{v}, \mathrm{A}$, and $\mathrm{Eg}$ represent the absorbance coefficient, Plank constant, frequency, proportionality constant, and band gap energy, respectively. Value $n$ used for $\mathrm{ZnO}$ is 2, because $\mathrm{ZnO}$ is a direct band gap semiconductor. Band gap energy was determined by plotting the Tauc plot $(\alpha h v)^{2}$ vs vs (hv). The band gap energy is obtained by extrapolating the linear curve to the $\mathrm{X}$-axis (hv). The Tauc plot of the undoped and Se doped $\mathrm{ZnO}$ sample were shown in Figure 4.
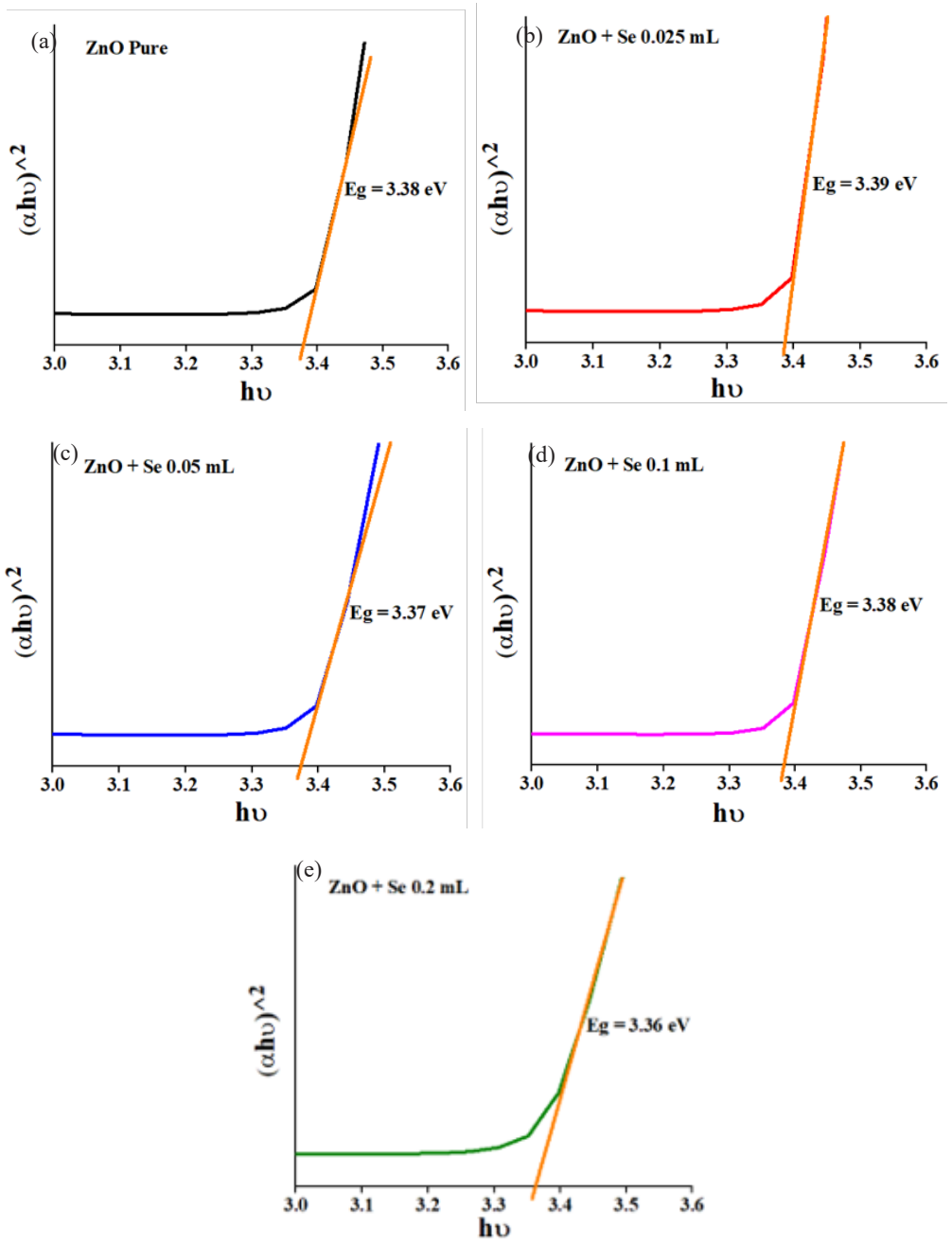

FIGURE 4. Tauc's plot of the undoped (a) and Se doped $\mathrm{ZnO}$ samples with different dopant volume (b) Se $0.025 \mathrm{~mL}$, (c) Se 0.05 $\mathrm{mL}$, (d) Se $0.1 \mathrm{~mL}$, and (e) Se $0.2 \mathrm{~mL}$ 
According to Figure 4(a), band gap energy of pure $\mathrm{ZnO}$ nanorods is $3.38 \mathrm{eV}$. Low addition of dopant volume less than $0.2 \mathrm{~mL}$ has slightly changed the band gap energy $\pm 0.01 \mathrm{eV}$. The lowest band gap energy is found in the sample with the addition of Se $0.2 \mathrm{~mL}(\sim 3.36 \mathrm{eV})$. The doping effect in semiconductor nanoparticles normally change both valence band (VB) or conduction band (CB) energy level, causing the widening or narrowing of the band gap (Walsh et al. 2008). According to the BursteinMoss theory, electrons donor in Se-doped $\mathrm{ZnO}$ occupy the bottom of the $\mathrm{ZnO}$ conduction band (Chen et al. 2017). A small decrease in the band gap energy in the $\mathrm{ZnO}+\mathrm{Se} 0.2$ $\mathrm{mL}$ sample indicates an additional energy bands from the doping element into the $\mathrm{ZnO}$ nanorods conduction band
(Ashari et al. 2016). The band gap energy reduction of the Se-doped $\mathrm{ZnO}$ nanorods sample was also obtained in the study of Taha et al. (2019). The reduction of band gap energy indicates that more valence band electron experience transition to the conduction band (Duan et al. 2006). However, increase of band gap energy caused by $\mathrm{ZnO}$ doping with Se might be occured after $\mathrm{Se} / \mathrm{ZnO}$ molar ratio of $1: 1$, as previously reported (Chen et al. 2017).

Figure 5 shows the photoluminescene spectra of doped and undoped $\mathrm{ZnO}$ nanorods. The peak emissions that occur in the sample are blue emission bands. This emission band is related to near band edge (NBE) caused by an oxygen vacancy (Kannappan \& Dhanasekaran 2014).

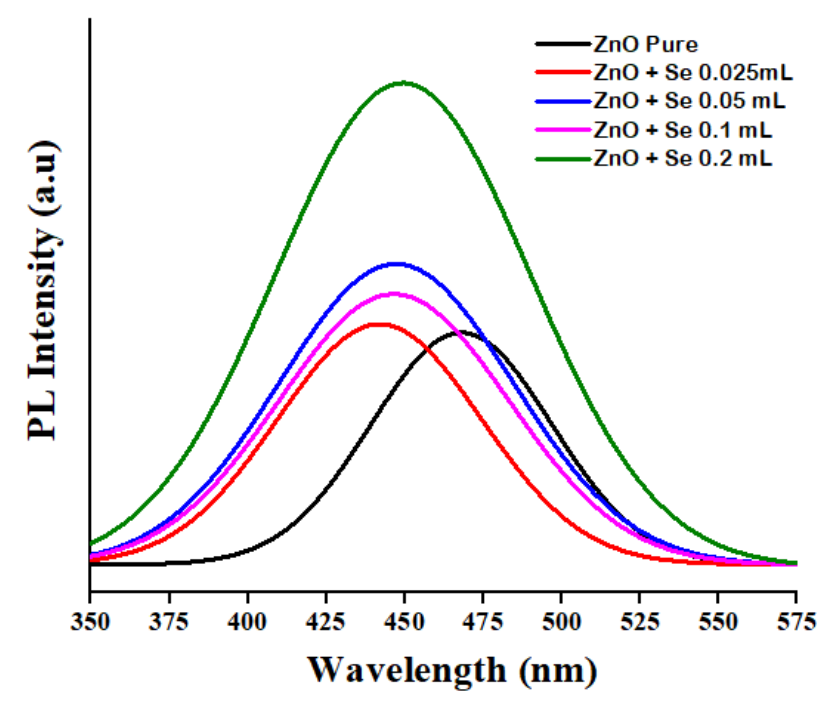

FIGURE 5. Photoluminescence spectra of $\mathrm{ZnO}$ pure and $\mathrm{Se}-\mathrm{ZnO}$

The peak of pure $\mathrm{ZnO}$ nanorods emission occurs at the wavelength of $470 \mathrm{~nm}$. On the other hand, with the addition of the Se element into $\mathrm{ZnO}$, the emission peak increases and shifts towards the greater energy. The raise in the intensity of the blue emission band attribute to an increase in the concentrations of Se atoms. This result was also obtained by Nenavathu et al. (2018) who doped 5\% of $\mathrm{Se}$ to $\mathrm{ZnO}$. The PL intensity of Se-doped $\mathrm{ZnO}$ nanoros is higher than pure $\mathrm{ZnO}$, indicating that the recombination of electrons and photo-induced holes still occurs (Chen et al. 2017). The shift in peak NBE emissions that occured can be ascribed to the incorporation of dopants, which causes a change in the band gap energy value.

\section{CONCLUSION}

In summary, undoped and Se-doped $\mathrm{ZnO}$ nanoparticles have been synthesized by the seed-mediated hydrothermal method. FESEM images show the samples are nanorod shaped. XRD analysis showed that the average crystallite size of obtained $\mathrm{ZnO}$ in the ranges of 35 to $42 \mathrm{~nm}$ with average aspect ratio of 1.6. The optical properties of $\mathrm{ZnO}$ pure and Se-doped $\mathrm{ZnO}$ was evaluated by UVVis reflectance and absorbance spectra. The band gap energy shows no significant changes that occurred with value $3.38 \mathrm{eV}$. Besides, the PL spectrum shows that the recombination of electrons and photogeneration of holes still occurs.

\section{ACKNOWLEDGEMENTS}

The authors thank the Institute of Microelectronic and Nanoengineering (IMEN), Universiti Kebangsaan Malaysia for the facilities during research and characterization. This project was partly funded by the Lembaga Penelitian 
dan Pengabdian Masyarakat, the University of Riau and partly supported by the Ministry of Higher Education, Malaysia under grant FRGS/1/2019/STG02/UKM/02/3.

\section{REFERENCES}

Abrar, I., Dee, C.F., Gebeshuber, I.C. \& Majlis, B.Y. 2012. Growth and characterization of indium doped $\mathrm{ZnO}$ nanowires using vapor transport deposition method. Advanced Materials Research 364: 202-205.

Achouri, F., Corbel, S., Balan, L., Mozet, K., Girot, E., Medjahdi, G., Said, M.B., Ghrabi, A. \& Schneider, R. 2016. Porous $\mathrm{Mn}$-doped $\mathrm{ZnO}$ nanoparticles for enhanced solar and visible light photocatalysis. Materials and Design 101: 309-316.

Alexandrov, A., Zvaigzne, M., Lypenko, D., Nabiev, I. \& Samokhvalov, P. 2020. Al-, Ga-, Mg-, or Li-doped zinc oxide nanoparticles as electron transport layers for quantum dot light-emitting diodes. Scientific Reports 10(1): 1-11.

Alshammari, A.S., Chi, L., Chen, X., Bagabas, A., Kramer, D., Alromaeh, A. \& Jiang, Z. 2015. Visible-light photocatalysis on C-doped $\mathrm{ZnO}$ derived from polymer-assisted pyrolysis. RSC Advances 5(35): 27690-27698.

Ashari, F., Chyi, J.L.Y., Talib, Z.A., Yunus, W.W.W., Jian, L.Y. \& Kee, L.H. 2016. Optical characterization of zinc selenide compound prepared through hydrothermal method. Materials Science Forum 846: 237-244.

Bae, S.Y., Seo, H.W. \& Park, J. 2004. Vertically aligned sulfurdoped $\mathrm{ZnO}$ nanowires synthesized via chemical vapor deposition. Journal of Physical Chemistry B 108(17): 5206-5210.

Bangbai, C., Chongsri, K., Pecharapa, W. \& Techitdeera, W. 2013. Effect of Al and N doping on structural and optical properties of sol-gel derives $\mathrm{ZnO}$ thin films. Sains Malaysiana 42(2): 239-246.

Chen, L.C., Tu, Y.J., Wang, Y.S., Kan, R.S. \& Huang, C.M. 2008. Characterization and photoreactivity of N-, S-, and C-doped $\mathrm{ZnO}$ under UV and visible light illumination. Journal of Photochemistry and Photobiology A: Chemistry 199(2-3): 170-178.

Chen, Y., Wang, L., Wang, W. \& Cao, M. 2017. Synthesis of Sedoped $\mathrm{ZnO}$ nanoplates with enhanced photoelectrochemical and photocatalytic properties. Materials Chemistry and Physics 199: 416-423.

Corral-Aguado, A., Martínez-Torres, P., Gomez-Ortiz, N., Pichardo-Molina, J., De la Rosa-García, S., Borjas-García, S.E. \& Medina, A. 2016. Synthesis of Mg doped $\mathrm{ZnO}$ with hexagonal shape by hydrothermal method. Microscopy and Microanalysis 22(S3): 1882-1883.

Duan, L., Lin, B., Zhang, W., Zhong, S. \& Fu, Z. 2006. Enhancement of ultraviolet emissions from $\mathrm{ZnO}$ films by $\mathrm{Ag}$ doping. Applied Physics Letters 88(23): 1-4.

Janotti, A. \& Van De Walle, C.G. 2009. Fundamentals of zinc oxide as a semiconductor. Reports on Progress in Physics 72(12): 1-29.

Kannappan, P. \& Dhanasekaran, R. 2014. Studies on structural and optical properties of ZnSe and ZnSSe single crystals grown by CVT method. Journal of Crystal Growth 401: 691-696.

Karim, S.S.A., Dee, C.F., Majlis, B.Y. \& Mohamed, M.A. 2019. Recent progress on fabrication of zinc oxide nanorod-based field effect transistor biosensors. Sains Malaysiana 48(6): 1301-1310.

Kim, S., Park, H., Nam, G., Yoon, H., Kim, B., Ji, I., Kim, Y., Kim, I., Park, Y., Kang, D. \& Leem, J.Y. 2014. Hydrothermally grown boron-doped $\mathrm{ZnO}$ nanorods for various applications: Structural, optical, and electrical properties. Electronic Materials Letters 10: 81-87.

Kumar, S.O., Soundeswaran, S. \& Dhanasekaran, R. 2002. Thermodynamic calculations and growth of $\mathrm{ZnSe}$ single crystals by chemical vapor transport technique. Crystal Growth and Design 2(6): 585-589.

Luo, J., Wang, Y. \& Zhang, Q. 2018. Progress in perovskite solar cells based on $\mathrm{ZnO}$ nanostructures. Solar Energy 163 : 289-306.

Mustafa, M.M., Ahmed, H.A.M., Taha, K.K. \& Mohammed, R. 2018. Synthesis and characterization of selenium doped zinc oxide (ZnO-Se) nanoparticles. International Journal of Current Research 10(9): 73644-73648.

Nenavathu, B.P., Sharma, A. \& Dutta, R.K. 2018. Se doped $\mathrm{ZnO}$ nanoparticles with improved catalytic activity in degradation of Cholesterol. Journal of Water and Environmental Technology 3(4): 289-300.

Patterson, A.L. 1939. The Scherrer formula for X-ray particle size determination. Physical Reviews 56(10): 978-982.

Rahman, M.Y.A., Roza, L., Umar, A.A. \& Salleh, M.M. 2016. Effect of dimethyl borate composition on the performance of boron doped $\mathrm{ZnO}$ dye-sensitized solar cell (DSSC). Journal of Materials Science: Materials in Electronics 27(3): 2228-2234.

Rong, P., Ren, S. \& Yu, Q. 2019. Fabrications and applications of $\mathrm{ZnO}$ nanomaterials in flexible functional devices - A review. Critical Reviews in Analytical Chemistry 49(4): 336-349.

Singh, S.C. 2013. Zinc oxide nanostructures: Synthesis, characterizations and device applications. Journal of Nanoengineering and Nanomanufacturing 3(4): 283-310.

Sutanto, H., Wibowo, S., Nurhasanah, I., Hidayanto, E. \& Hadiyanto, H. 2016. Ag doped $\mathrm{ZnO}$ thin films synthesized by spray coating technique for methylene blue photodegradation under UV irradiation. International Journal of Chemical Engineering 2016: 1-6.

Taha, K.K., Mustafa, M.M., Ahmed, H.A.M. \& Talab, S. 2019. Selenium zinc oxide $(\mathrm{Se} / \mathrm{ZnO})$ nanoparticles: Synthesis, characterization, and photocatalytic activity. Zeitschrift für Naturforschung A 74(12): 1043-1056.

Tan, R., Zhang, Y.L., Yang, Y., Song, W., Xu, T.F. \& Nie, Q. 2009. Pyroelectric properties of $\mathrm{ZnO}$-based nanostructured polycrystalline ceramics. International Symposium on Photoelectronic Detection and Imaging 2009: Material and Device Technology for Sensors. doi.org/10.1117/12.836518.

Thangavel, R. \& Chang, Y.C. 2012. Investigations on structural, optical and electrical properties of p-type $\mathrm{ZnO}$ nanorods using hydrothermal method. Thin Solid Films 520(7): 25892593.

Thu, T.V. \& Maenosono, S. 2010. Synthesis of high-quality Aldoped ZnO nanoink. Journal of Applied Physics 107(1): 1-6.

Walsh, A., Da Silva, J.L.F. \& Wei, S.H. 2008. Origins of band-gap renormalization in degenerately doped semiconductors. Physical Review B 78(7): 075211. 
Wang, M., Ren, F., Zhou, J., Cai, G., Cai, L., Hu, Y., Wang, D., Liu, Y., Guo, L. \& Shen, S. 2015. N doping to ZnO nanorods for photoelectrochemical water splitting under visible light: Engineered impurity distribution and terraced band structure. Scientific Reports 5: 1-13.

Wang, X., Huang, H., Liang, B., Liu, Z., Chen, D. \& Shen, G. 2013. ZnS nanostructures: synthesis, properties, and applications. Critical Reviews in Solid State and Materials Sciences 38(1): 57-90.

Wang, Y., Zhong, M., Wang, W., Wang, Q., Wu, W. \& Luo, X. 2019. Effects of ZnSe modification on the perovskite films and perovskite solar cells based on $\mathrm{ZnO}$ nanorod arrays. Applied Surface Science 495: 1-30.

Yilmaz, S., McGlynn, E., Bacaksiz, E., Cullen, J. \& Chellappan, R.K. 2012. Structural, optical and magnetic properties of Nidoped $\mathrm{ZnO}$ micro-rods grown by the spray pyrolysis method. Chemical Physics Letters 525-526: 72-76.

Zakaria, M.R., Johari, S., Ismail, M.H. \& Hashim, U. 2017. Characterization of zinc oxide $(\mathrm{ZnO})$ piezoelectric properties for surface acoustic wave (SAW) device. International Conference on Applied Photonics and Electronics 2017 (InCAPE2017). Avillion Port Dickson, Malaysia. p. 01055.

Zhu, L. \& Zeng, W. 2017. Room-temperature gas sensing of ZnO-based gas sensor: A review. Sensors and Actuators A: Physical 267: 242-261.
Ari Sulistyo Rini*, Yolanda Rati, Miranti Agustin \& Yanuar Hamzah

Department of Physics

Faculty of Mathematics and Natural Science

Universitas Riau

Kampus Bina Widya

Jl. H.R Soebrantas Km 12.5, Simpang Baru

Pekanbaru, 28293

Indonesia

Akrajas Ali Umar

Institute of Microengineering and Nanoelectronics (IMEN)

Universiti Kebangsaan Malaysia

43600 UKM Bangi, Selangor Darul Ehsan

Malaysia

*Corresponding author; email: ari.sulistyo@lecturer.unri.ac.id

Received: 18 August 2020

Accepted: 27 August 2020 